\title{
Electrochemical Methods for Evaluation of Antioxidant Properties of Propolis Extract Incorporated in Chitosan Nanoparticles
}

\author{
LUMINITA FRITEA ${ }^{1 \#}$, PAULA MELANIA PASCA ${ }^{2 \#}$, LAURIAN VLASE ${ }^{3}$, \\ ANA-MARIA GHELDIU ${ }^{4}$, LIVIU MOLDOVAN ${ }^{5}$, FLORIN BANICA ${ }^{6 *}$, \\ LUCIANA DOBJANSCHI ${ }^{*}$, SIMONA CAVALU ${ }^{1}$ \\ ${ }^{1}$ University of Oradea, Faculty of Medicine and Pharmacy, Department of Preclinical Disciplines, 101 Decembrie Sq., \\ 410073, Oradea, Romania \\ ${ }^{2}$ University of Oradea, Faculty of Medicine and Pharmacy, Doctoral School of Biomedical Sciences, 101 Decembrie Sq., \\ 410073, Oradea, Romania \\ ${ }^{3}$ Iuliu Hatieganu University of Medicine and Pharmacy, Faculty of Pharmacy, Department of Pharmaceutical Technology \\ and Biopharmaceutics, 8 Victor Babes Str., 400012, Cluj-Napoca, Romania \\ ${ }^{4}$ Iuliu Hatieganu University of Medicine and Pharmacy, Faculty of Pharmacy, Department of Pharmaceutical Botany, \\ 8 Victor Babes Str., 400012, Cluj-Napoca, Romania \\ ${ }^{5}$ University of Oradea, Faculty of Electrical Engineering and Information Technology, Department of Electronics and \\ Telecommunications, 1 Universității Str., 410087, Oradea, Romania \\ ${ }^{6}$ University of Oradea, Faculty of Medicine and Pharmacy, Department of Pharmacy, 29 Nicolae Jiga Str., 410028, Oradea, \\ Romania
}

\begin{abstract}
The main purpose of our study was to demonstrate the antioxidant properties of novel propolis nano-formulation, incorporated in spherical chitosan nanoparticles. The electrochemical methods (cyclic voltammetry and differential pulse voltammetry) were successfully applied to propolis extract and nanopropolis formulation, confirming that the content in phenolic acids and flavonoids is responsible for the antioxidant activity of propolis. The quantitative and qualitative results are also supported by high performance liquid chromatography (HPLC) and ultraviolet-visible (UV-Vis) spectroscopy.
\end{abstract}

Keywords: propolis nano-formulation, chitosan, voltammetry, HPLC, UV-Vis spectroscopy.

\section{Introduction}

Propolis, or "bee glue" is a natural product, sticky and resinous, resulting from a mixture of bees' salivary secretion and exudates from plants, as a method of defense against microbes and moulds. The biological and pharmacological properties of propolis are well documented, including antibacterial, antifungal, anti-inflammatory, antiviral and antioxidant activities (among others) and reported by many researchers [1-4]. The complex chemical composition of propolis extracts includes high content of active compounds such as phenolic acids and flavonoids $[2,5]$, both being considered as secondary metabolites. Phenolic compounds activity is related to their disrupting action on the bacterium cell wall, interfering with ATP molecules and hence, altering its membrane potential which results in the bacterium's death [5]. The antioxidant activity of propolis has been traditionally correlated to the amount of phenolic compounds in extracts, the mechanism of action being related to the ability to scavenge the free radicals involved in oxidative stress [6]. On the other hand, the flavonoids action is based on the inhibition of DNA, RNA and proteins synthesis by bacteria, altering their membrane permeabilization [5]. It was previously demonstrated that propolis collected from tempered geographic areas is rich in flavonoids and aromatic acids, while propolis from tropical area usually presents high phenolic acids content [7].

As the administration of phenolic compounds requires a special formulation with protecting systems, able to maintain the structural integrity of the bioactive compounds until the moment of consumption, micro and nano-encapsulation techniques have emerged as a prominent solution to the bioavailability of the therapeutic agent [8]. Chitosan is one of the most suitable and affordable natural polymers used as a 
drug delivery system, owing to its special properties: biocompatible, biodegradable, non-toxic and nonimmunogenic [9-10]. At acid $p \mathrm{H}$, its amino groups are ionized, making it hydrosoluble and positively charged; these properties enable it to interact with oppositely charged polymers by intermolecular electrostatic interaction, forming polyelectrolyte complexation.

Even if there are some previous studies in literature reporting chitosan-propolis nanoparticles formulation $[8,11,12]$, the novelty of our work is related to using an aqueous extract of propolis instead of an ethanolic one. The previous results reported in literature demonstrated the antimicrobial activity of nanopropolis formulations against Staphylococcus aureus, Candida albicans and Enterococcus faecalis, but the propolis extraction was performed exclusively using organic solvents. As a general aspect, most of the studies available in the literature are carried out with a propolis ethanolic extract, and therefore little is known about the biological activity of the propolis water extract [13]. Moreover, Pereira et al. [14] observed a genotoxic activity of ethanol extract of propolis when using doses higher than 1000 $\mathrm{mg} / \mathrm{kg}$. In our study, the antioxidant capacity of aqueous versus ethanolic propolis extract was evaluated.

Both spectrophotometric and electrochemical assays can be used in order to evaluate the antioxidant capacity of natural biological compounds, including the propolis extract. Spectrophotometric assays are based on the redox reaction with an oxidant: TEAC (Trolox Equivalent capacity, FRAP (ferric ion reducing antioxidant parameter), DPPH ((2,2-diphenyl-1-picryl-hydrazyl-hydrate), CUPRAC (Cu(II) reduction capacity) and Folin-Ciocalteu assay for total phenolics determination [15-21]. The main drawbacks of these methods are related to the high cost of reactants and different interferences with other colorful compounds in the sample. Another spectroscopic approach is the determination of total content of flavonoids by UV-Vis analysis [22-25], while the UV-Vis characterization of the propolis extract pointed out the content of phenolic compounds with $\pi$ conjugated aromatic rings [26-27]. The advantages of electrochemical methods result from the relationship between electrochemical behavior and antioxidant power of phenolic compounds: a low oxidation potential is associated with a high antioxidant power [28]. The electrochemical method is based on the measurement of anodic current intensity, which is related to the total content of the reducing species present in the sample, and hence, is considered a rapid, easy and low cost tool for evaluation of antioxidant capacity of propolis extracts from different origins [26-31].

HPLC is an important and specific analytical method used for qualitative and quantitative determination of natural products [32-38]. The most used technique for the chemical analysis of propolis are the spectrophotometric and chromatographic methods [2]. The phytochemical profile of the propolis samples is very important because the content in phenolic acids and flavonoids is responsible for their antioxidant activity.

The aim of our work was to determine the antioxidant capacity of novel nano-formulation based on chitosan nanoparticles incapsulating propolis extract, along with the evaluation of antioxidant capacity of different propolis extracts (aqueous and ethanolic) originated from Nord West area of Romania (Bihor County). The size and morphology of the chitosan/propolis nanoparticles was assessed by dynamic light scattering (DLS) and electronic microscopy, the antioxidant capacity was evaluated by electrochemical method, meanwhile their chemical composition was studied by chromatographic and spectrophotometric methods.

\section{Materials and methods}

\subsection{Preparation of chitosan/propolis nanoparticles}

Chitosan powder (medium molecular weight, deacetylation degree $>75 \%$ ) and sodium tripolyphosphate (TPP) $\left(\mathrm{Na}_{5} \mathrm{P}_{3} \mathrm{O}_{10}\right)$, were obtained from Sigma-Aldrich, while propolis extracts $(30 \%$, both aqueous and ethanolic) were purchased from S.C. PHENALEX SRL (Romanian private company). Chitosan was dissolved in $2 \%$ acetic acid obtaining a solution with concentration of $0.32 \%(\mathrm{w} / \mathrm{v})$, in which propolis extract was added, accompanied by continuous magnetic stirring for $1 \mathrm{~h}$. As a crosslinker, $10 \mathrm{~mL}$ TPP solution $0.4 \%$ was injected slowly using a syringe, while stirring for $30 \mathrm{~min}$. The obtained suspension was centrifuged at $15000 \mathrm{rpm}$, for another $30 \mathrm{~min}$, until the precipitate was formed. 
The precipitate was filtered and washed with distilled water, three times, and then freeze dried using Martin Christ Alpha 1-2 LD equipment. The obtained powder was analyzed by TEM (TECNAI G2 F30 S-TWIN, FEI) and DLS (Dynamic Light Scattering, ZEN 3690 Malvern Instruments, UK), re-suspended in distilled water and sonicated for $10 \mathrm{~min}$ before each measurement, in order to avoid the spontaneous agglomeration.

\subsection{Electrochemistry measurements}

Ascorbic acid, $\mathrm{CH}_{3} \mathrm{COOH}$ and $\mathrm{CH}_{3} \mathrm{COONa}$ were purchased from Sigma and used as received. Nanopropolis was dissolved in acetate buffer $(0.1 \mathrm{M}, p \mathrm{H} 4.65)$ by ultrasonication and heating (chitosan is soluble in acidic medium). Acetate buffer was the electrolyte used for all the electrochemical measurements.

The electrochemical experiments were carried out by using a three-electrode electrochemical cell with glassy carbon electrode (GCE) as working electrode (3 $\mathrm{mm}$ diameter, BAS), Pt wire as counter electrode and $\mathrm{Ag} / \mathrm{AgCl}$ as reference electrode, connected to a potentiostat (PGSTAT 128N Autolab, Metrohm, Belgium) equipped with Nova 2.1.2 software. The working electrode was polished with diamond paste $(2 \mu \mathrm{m})$ and rinsed with ethanol and distilled water before every use. The electrochemical behavior of propolis extracts, nanopropolis and ascorbic acid was studied by using cyclic voltammetry (CV) and differential pulse voltammetry (DPV) [26, 28-30]. CV was used for scan rate variation employing the following parameters: start potential $0 \mathrm{~V}$, upper vortex potential $+1 \mathrm{~V}$, lower vortex potential $-0.1 \mathrm{~V}$, stop potential $0 \mathrm{~V}, 1$ scan. DPV was performed for the other experiments using the parameters: start potential $-1 \mathrm{~V}$, stop potential $+1.5 \mathrm{~V}$, step $0.01 \mathrm{~V}$, modulation amplitude $0.05 \mathrm{~V}$, modulation time $0.05 \mathrm{~s}$, interval time $0.1 \mathrm{~s}$. Ascorbic acid was used as a standard for the calculation of propolis antioxidant capacity [29-30].

\subsection{HPLC analysis}

All the reagents were purchased from Sigma Aldrich and the solvents were of HPLC grade. The nanopropolis was dissolved in $2 \%$ acetic acid.

The phytochemical composition of nanopropolis and propolis extracts were assessed by using an Agilent 1100 HPLC Series system (Agilent, Santa Clara, CA, USA) with UV detector and coupled with an Agilent Ion Trap 1100 SL mass spectrometer. Two methods were employed for the identification and quantification of polyphenolic compounds as performed by Rusu and co-workers [32].

First method used standards of 18 polyphenols (caftaric acid, gentisic acid, caffeic acid, chlorogenic acid, p-coumaric acid, ferulic acid, sinapic acid, hyperoside, isoquercitrin, rutozid, myricetol, fisetin, quercitrin, quercetin, patuletin, luteolin, kaempferol, and apigenin), meanwhile the second one used 6 polyphenols standards (epicatechin, catechin, syringic acid, gallic acid, protocatechuic acid and vanillic acid) [32]. The chromatographic measurements were performed by using a reverse-phase analytical column (Zorbax SB-C18, $100 \mathrm{~mm}$ x $3.0 \mathrm{~mm}$ i.d., $3.5 \mathrm{um}$ ) and a mobile phase consisting in a mixture of methanol: $0.1 \%$ acetic acid (v/v) and a binary gradient (for the first method - beginning with $5 \%$ methanol and ending at $42 \%$ methanol at $35 \mathrm{~min}$; then the next $3 \mathrm{~min}$ with $42 \%$ methanol and in the next 7 min with 5\% methanol; for the second method - 3\% methanol at start, $8 \%$ methanol at 3 min, $20 \%$ methanol at $8.5 \mathrm{~min}, 20 \%$ methanol until $10 \mathrm{~min}$, then $3 \%$ methanol) [32]. A flow rate of $1 \mathrm{~mL} / \mathrm{min}$ and an injection volume of $5 \mu \mathrm{L}$ were employed. Until 17 min the UV detector was set at $330 \mathrm{~nm}$ (for the detection of polyphenolic acids), then until $38 \mathrm{~min}$ at $370 \mathrm{~nm}$ (for the detection of flavonoids and their aglycones) [32]. The MS detector using an electrospray ion source in negative mode had the following parameters: capillary $+3000 \mathrm{~V}$, nebulizer 60 psi (nitrogen), dry gas nitrogen at $12 \mathrm{~L} / \mathrm{min}$, dry gas temperature $360^{\circ} \mathrm{C}[32]$. 


\subsection{Spectrophotometric analysis}

The analytes were dissolved or diluted in acetate buffer (as mentioned in the previous section 2.1). The spectrophotometric measurements were carried out by using a spectrophotometer (PG Instruments T70 UV-VIS, UK) equipped with UVWIN software and quartz cuvettes.

\section{Results and discussions}

\subsection{Morphological characterization of chitosan/propolis nanoparticles}

DLS measurements were applied in order to evaluate the average particle size and zeta potential, the results being presented in Figure 1(a,b).

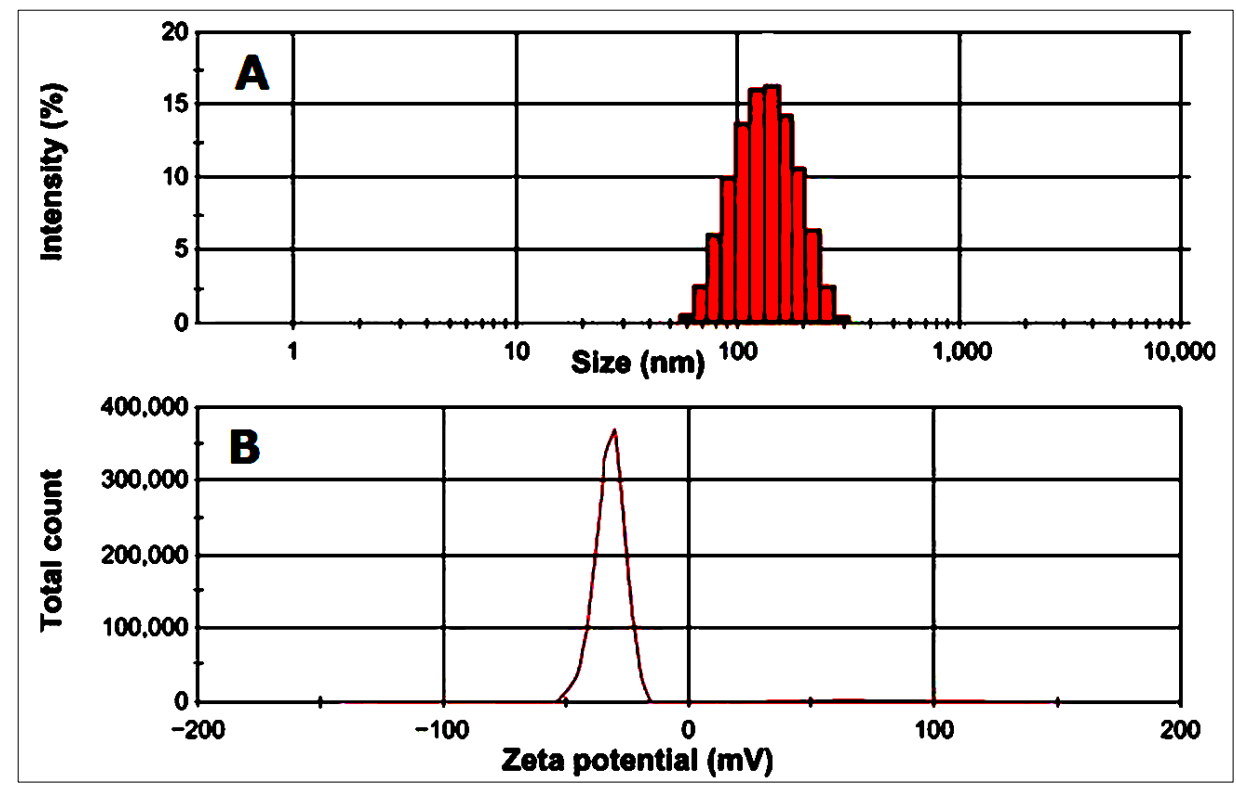

Figure 1. Size distribution and average diameter of chitosan/propolis nanoparticles (A) and corresponding Zeta potential (B)

The diagram presented in Figure 1 indicated a maximum size distribution around $140 \mathrm{~nm}$ (Gaussian distribution), while a value of $31.5 \mathrm{mV}$ was recorded for Zeta potential, indicating a good stability of the nanoparticles in suspension. The morphology of chitosan/propolis nanoparticles was evidenced by TEM micrographs in Figure 2, along with the elemental analysis by energy dispersive X-ray analysis (EDAX).

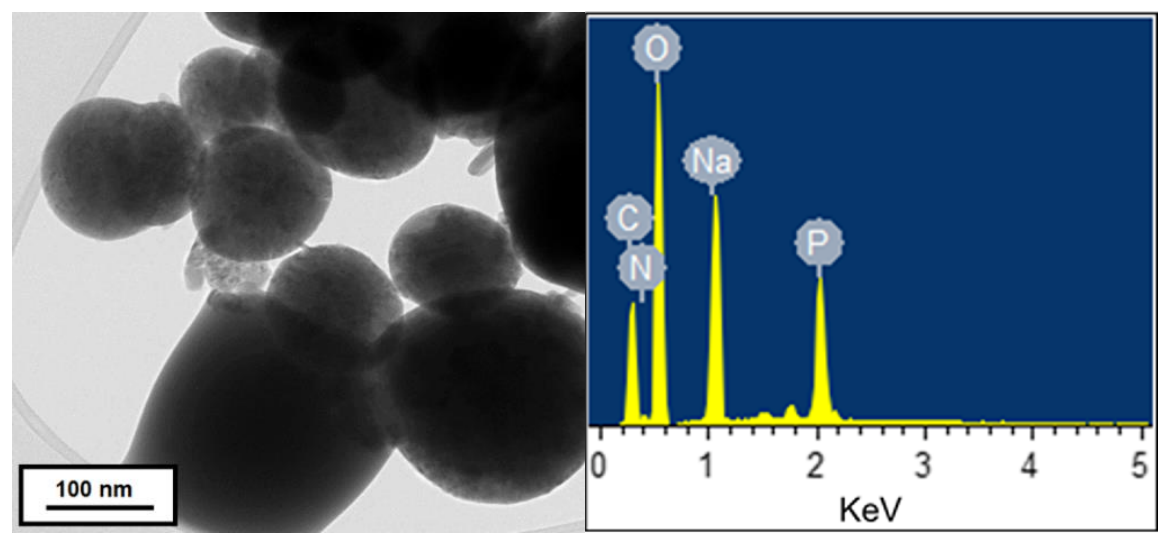

Figure 2. Morphology of chitosan/propolis nanoparticles evidenced by TEM/EDAX

The images revealed the spherical shape of nanoparticles, and their diameter ranging from 100 to $200 \mathrm{~nm}$, in concordance with the DLS results. By comparing these results with our previously reported 
ones [8], a smaller diameter and regular shape can be noticed, demonstrating that the above preparation method is more adequate for pharmaceutical applications. The present results are also supported by other researches in this field, which demonstrated that the production of nanoparticles by ionic gelation results in smaller particles for higher amounts of cross-linker, providing sufficient protonation of chitosan for interaction with TPP [39-40].

\subsection{Electrochemical characterization}

Both types of commercial propolis extracts (aqueous and alcoholic) were analyzed by DPV (Figure 3A) revealing an oxidation process with a first significant peak at around $380 \mathrm{mV}$ and other small peaks like shoulders. All these signals were due to the complex chemical composition of propolis extracts in electroactive species. Masek et al. and Falcao et al. have also identified at least two distinct electrooxidation signals in propolis extracts $[26,28]$. The chitosan/propolis nanoparticles were also tested by the DPV method showing a similar electrochemical behavior in the oxidation range of the potential (Figure 3B) to the parent commercial extracts. However, in the case of chitosan/propolis nanoparticles, these anodic peaks were better defined and separated in comparison with the ones registered for simple extracts. Furthermore, the first peak was shifted at $350 \mathrm{mV}$, this being a proof of the electrocatalytic effect which was probably due to the new way of presenting propolis. The intensity of the oxidation signals corresponding to a nanopropolis suspension of $10 \mathrm{mg} / \mathrm{mL}$ were higher than for $2 \mathrm{mg} / \mathrm{mL}$ nanopropolis indicating a higher antioxidant power due to a more increased concentration of antioxidants.

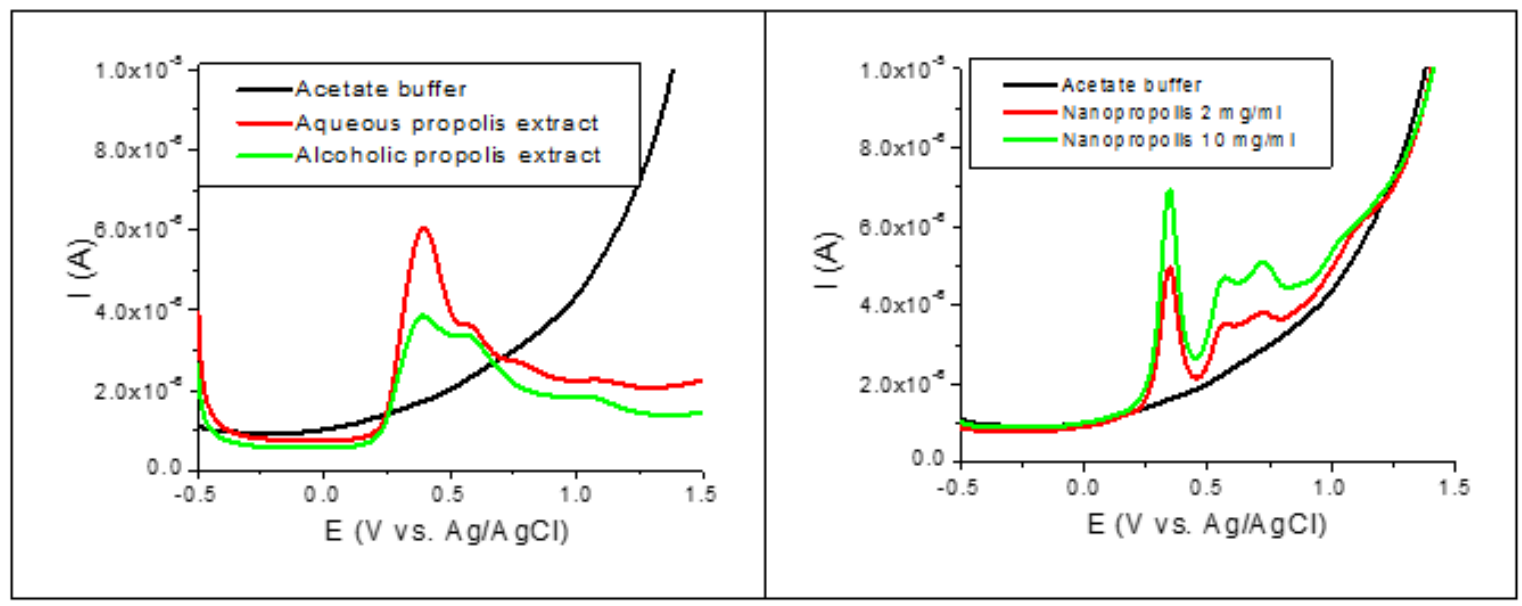

Figure 3. DPVs of (A) aqueous and alcoholic propolis extract (1:10) and of (B) nanopropolis $2 \mathrm{mg} / \mathrm{mL}, 10 \mathrm{mg} / \mathrm{mL}$

The solution of nanopropolis was spiked with aqueous extract, the intensity peak height of all the oxidation peaks was increased (Figure 4A) without potential shifting. This indicated that the chitosan/propolis nanoparticles contained the same compounds as the extract which was entrapped inside the nanoparticles. The nanopropolis oxidation process was compared with that of ascorbic acid usually used as a standard substance for evaluation of antioxidant activity. It was observed that the presence of ascorbic acid caused the increase in the intensity of the first oxidation peak current, together with a potential shift towards higher values for all the anodic peaks with about 10-20 mV (Figure 4B). 


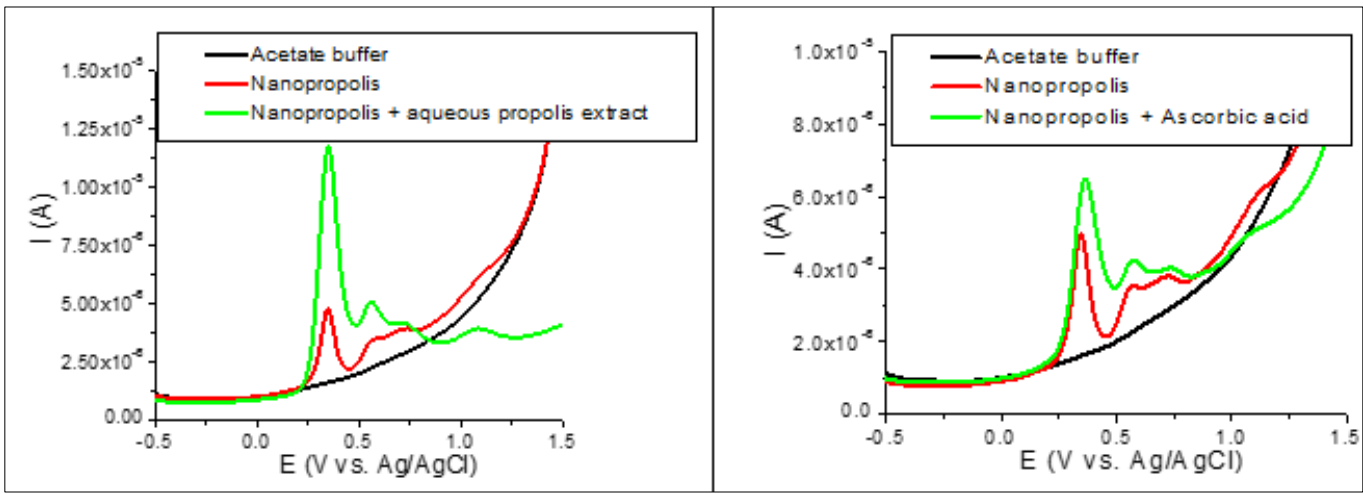

Figure 4. DPVs of nanopropolis $2 \mathrm{mg} / \mathrm{mL}$ and addition of (A) aqueous propolis extract $(500 \mu \mathrm{L})$ and $(\mathrm{B})$ ascorbic acid $\left(500 \mu \mathrm{L}\right.$ ascorbic acid $\left.10^{-2} \mathrm{M}\right)$

$\mathrm{CV}$ was also employed in order to assess the nanopropolis electrochemical behavior with the scan rate variation (Figure 5A). It can be observed that the $\mathrm{CV}$ registered for nanopropolis presented three different oxidation peaks and one reduction peak in the considered potential range. The potential of the first anodic peak was shifted towards positive values with the scan rate increase (by around $30 \mathrm{mV}$ ), while the cathodic peak potential moved towards negative values (by around $70 \mathrm{mV}$ ). The $\Delta$ Ep increased from $119 \mathrm{mV}$ to $212 \mathrm{mV}$ indicating an irreversible reaction for the propolis redox process. The intensity of the redox peaks varied linearly with the square root of the scan rate. The equation for the oxidation process of the first peak was $\mathrm{y}=2.918 \cdot 10^{-7} \cdot \mathrm{x}-9.043 \cdot 10^{-7}, \mathrm{R}^{2}=0.993$, while the equation for the reduction process was $\mathrm{y}=-9.515 \cdot 10^{-8} \cdot \mathrm{x}+4.026 \cdot 10^{-7}, \mathrm{R}^{2}=0.987$. These results indicated that the nanopropolis electrochemical activity was controlled by the diffusion of the electroactive species towards the electrode surface.

Three anodic peaks and one cathodic peak appeared in the CVs registered for nanopropolis, similar results being also reported by other authors for different propolis extracts [26-28, 30]. The oxidation peaks from around $400 \mathrm{mV}, 600 \mathrm{mV}$ and $800 \mathrm{mV}$, respectively were assigned to the flavonoids electrochemical oxidation, while the first oxidation peak having the highest intensity was assigned to the catechol groups, as already reported by other authors [27-28, 30].
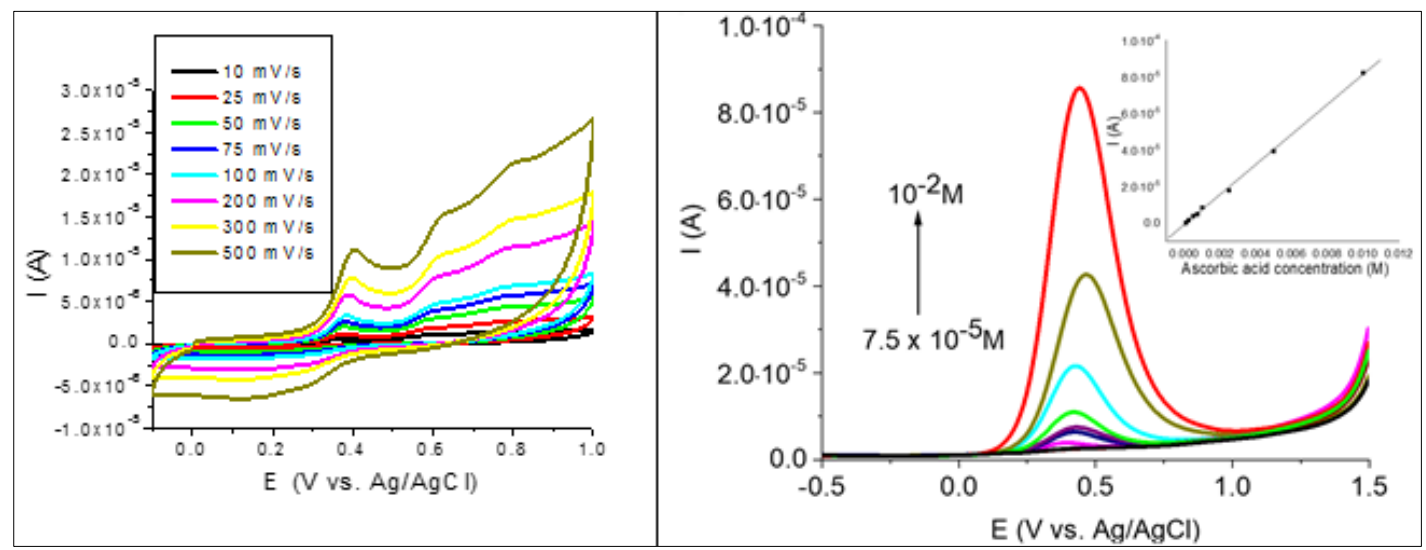

Figure 5. (A) CVs of nanopropolis $10 \mathrm{mg} / \mathrm{mL}$ at different scan rates, (B) DPV of ascorbic acid at different concentrations $\left(7.5 \times 10^{-5} \mathrm{M}, 10^{-4} \mathrm{M}, 2.5 \times 10^{-4} \mathrm{M}, 5 \times 10^{-4} \mathrm{M}\right.$, $\left.7.5 \times 10^{-4} \mathrm{M}, 10^{-3} \mathrm{M}, 2.5 \times 10^{-3} \mathrm{M}, 5 \times 10^{-3} \mathrm{M}, 10^{-2} \mathrm{M}\right)$ and inset of calibration plot

The antioxidant potential of nanopropolis was evaluated based on the ascorbic acid equivalent antioxidant capacity (AEAC). For this reason, solutions of ascorbic acid of different concentrations in the range $7.5 \cdot 10^{-5} \mathrm{M}-10^{-2} \mathrm{M}$ were tested by DPV revealing an anodic peak at around $400 \mathrm{mV}$, as also reported by other authors [29-30, 41-43]. The equation obtained from the calibration graph for ascorbic 
acid was $y=0.008 \cdot x-7.383 \cdot 10^{-7}$ with a correlation coefficient of $\mathrm{R}^{2}=0.998$ (Figure 5B). By using this equation, the AEAC of aqueous propolis extract was calculated to be $399.5 \mathrm{mg} / \mathrm{g}(39.95 \%)$ and that of nanopropolis $350.4 \mathrm{mg} / \mathrm{g}(35.04 \%)$ with an RSD of $2.36 \%$. These results indicated an efficiency entrapping of propolis in chitosan nanoparticles of $87.71 \%$.

Belfar et al. have studied the antioxidant capacity of Algerian propolis expressed as ascorbic acid equivalents ranging between 74.568-177.251 mg/g (CV) and 22.197-62.688 mg/g (SWV), meanwhile Rebiai et al. have calculated $5.125 \mathrm{mg} / \mathrm{g}$ AEAC (CV) [29-30]. Indian propolis extracts were found to contain $87 \mathrm{mg} / \mathrm{g}$ and $136 \mathrm{mg} / \mathrm{g}(\mathrm{CV})$ of ascorbic acid equivalents [31].

\subsection{Chromatographic characterization}

The HPLC chromatograms revealed the phytochemical profiles of the aqueous propolis extract and nanopropolis (Figure 6 and Figure 7). By employing the first chromatographic method, six polyphenols were identified in the aqueous propolis extract (Table 1). The compound found in the highest concentration was caffeic acid $(174.827 \mu \mathrm{g} / \mathrm{mL})$, meanwhile apigenin and kaempferol were other flavonoids present in significant amounts (Table 1). In the case of the nanopropolis analysis, the same caffeic acid was quantified in the highest concentration $(2.971 \mu \mathrm{g} / \mathrm{mL})$, meanwhile apigenin, ferulic acid and p-coumaric acid were detected in considerable amounts (Table 2).

The second chromatographic method indicated the presence of two phenolic acids, protocatechuic acid and vanillic acid. Aqueous propolis extract contained $1.47 \mu \mathrm{g} / \mathrm{mL}$ of protocatechuic acid and $2.14 \mu \mathrm{g} / \mathrm{mL}$ of vanillic acid. Nanopropolis presented $0.04 \mu \mathrm{g} / \mathrm{mL}$ of protocatechuic acid and $0.36 \mu \mathrm{g} / \mathrm{mL}$ of vanillic acid.

Other significant peaks which have not been confirmed with standards (with retention time at about $8.7 \mathrm{~min}, 12 \mathrm{~min}$ and $13.8 \mathrm{~min}$ ) can be observed in the chromatograms. According to the literature, those peaks could be attributed to vanillin, 3,4-dimethoxycinnamic acid and pinobanksin [44-46].

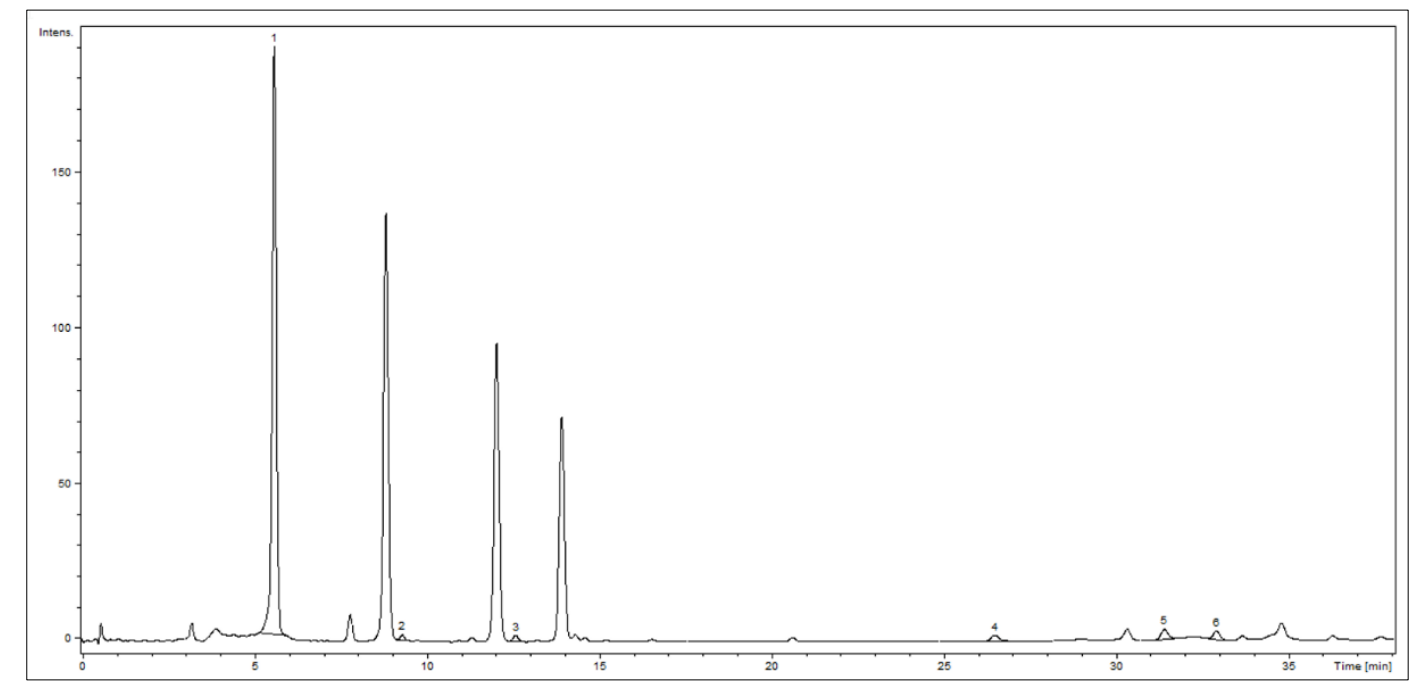

Figure 6. HPLC chromatogram of aqueous propolis extract

Table 1. Polyphenolic compounds found in aqueous propolis extract.

\begin{tabular}{|c|c|c|c|c|}
\hline $\begin{array}{c}\text { No. on } \\
\text { chromatogram }\end{array}$ & Compound & $\begin{array}{c}\text { Identified by } \\
\mathbf{U V}\end{array}$ & $\begin{array}{c}\text { Identified by } \\
\mathbf{M S}\end{array}$ & $\begin{array}{c}\text { Concentration } \\
(\boldsymbol{\mu g} / \mathbf{m L})\end{array}$ \\
\hline 1 & Caffeic acid & YES & YES & 174.827 \\
\hline 2 & p-coumaric acid & YES & YES & 2.005 \\
\hline 3 & Ferulic acid & YES & YES & 2.530 \\
\hline 4 & Quercetin & YES & YES & 4.288 \\
\hline 5 & Kaempferol & YES & YES & 8.170 \\
\hline 6 & Apigenin & YES & YES & 9.780 \\
\hline
\end{tabular}




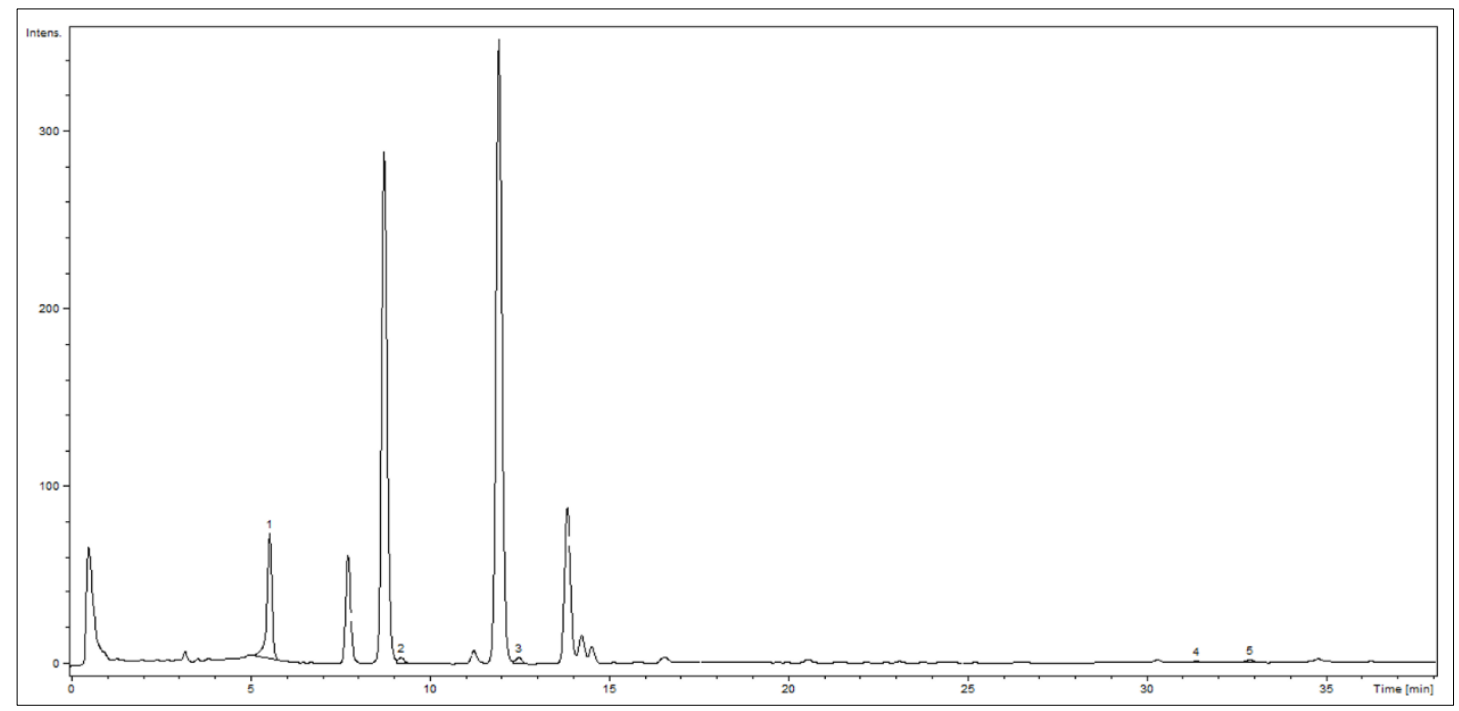

Figure 7. HPLC chromatogram of nanopropolis $(10 \mathrm{mg} / \mathrm{mL})$

Table 2. Polyphenolic compounds found in nanopropolis $(10 \mathrm{mg} / \mathrm{mL})$

\begin{tabular}{|c|c|c|c|c|}
\hline $\begin{array}{c}\text { No. on } \\
\text { chromatogram }\end{array}$ & Compound & $\begin{array}{c}\text { Identified by } \\
\mathbf{U V}\end{array}$ & $\begin{array}{c}\text { Identified by } \\
\mathbf{M S}\end{array}$ & $\begin{array}{c}\text { Concentration } \\
(\boldsymbol{\mu} \mathbf{g} / \mathbf{m L} \mathbf{)}\end{array}$ \\
\hline 1 & Caffeic acid & YES & YES & 2.971 \\
\hline 2 & p-coumaric acid & YES & YES & 0.189 \\
\hline 3 & Ferulic acid & YES & YES & 0.212 \\
\hline- & Quercetin & NO & YES & - \\
\hline 4 & Kaempferol & YES & YES & 0.075 \\
\hline 5 & Apigenin & YES & YES & 0.244 \\
\hline
\end{tabular}

Propolis samples from various countries from all over the world have been intensively studied regarding their phytochemical analysis [37, 45-47].The phenolic profile of propolis extracts from various areas from Azerbaijan indicated the presence of 7 phenolic acids (the most abundant being caffeic acid between 3-532 $\mathrm{mg} / 100 \mathrm{~g}$ ) and 6 flavonoids (apigenin being the most abundant with a concentration between 17.70-180.72 mg/100g) [48].The essential phenolic compounds found in propolis extracts from Turkey were naringenin, pinocembrin and galangin $(2.45 \mathrm{mg} / \mathrm{mL}, 9.92 \mathrm{mg} / \mathrm{mL}$ and $7.06 \mathrm{mg} / \mathrm{mL}$, respectively) [49]. Chrysin was the main flavonoid found in Brasilian propolis with a concentration between 1800.81-9742.99 $\mu \mathrm{g} / \mathrm{mL}$ [50]. Coneac et al. have identified in the propolis samples from western Romania the following compounds: caffeic acid, rutin, quercetin, apigenin and chrysin [2]. All the 53 samples of propolis from Transylvania investigated in a study contained phenolic acids: caffeic, p-coumaric, and ferulic and also chrysin (chrysin was quantified in higher amounts, $1.6 \mathrm{mg} / \mathrm{g}$ ) [2]. The Romanian propolis samples studied by Gatea et al. have revealed large amounts of flavonoids (quercetin, naringenin, kaempferol, chrysin, galangin, pinocembrim and pinostrobin) and phenolic acids (caffeic acid 2-phenylethyl ester, ferulic acid, caffeic acid, coumaric acid and cinnamic acid) [51]. The nonhydrolyzed and hydrolyzed Romanian propolis samples evaluated by Bolfa et al. presented the highest concentration of p-coumaric acid $(427.358 \mu \mathrm{g} / \mathrm{mL}, 505.961 \mu \mathrm{g} / \mathrm{mL})[52]$.

\subsection{Spectrophotometric characterization}

UV-Vis spectra of propolis extract and nanopropolis were recorded observing peaks at $300 \mathrm{~nm}$ (corresponding to the aqueous propolis extract) and at $290 \mathrm{~nm}$ and $310 \mathrm{~nm}$ (for the nanopropolis sample) (Figure 8), similarly with other types of propolis from some studies [2, 26-27]. Meanwhile ascorbic acid presents absorbance at $260 \mathrm{~nm}$ [53]. The peaks from the UV-Vis spectra confirmed the phenolic compounds from propolis extract and nanopropolis revealed by the HPLC analysis, knowing from the 
literature that these compounds are visible in the range 280-350 $\mathrm{nm}[2,26-27]$. According to the classification of propolis types mentioned by Marghitas et al. [2], the propolis extract could be integrated in type 3 (with a total flavonoid content of 5-8\%), meanwhile the nanopropolis could be included in type 2 (with approximatively $5 \%$ of total flavonoid content). This aspect indicated a slight reduction of total flavonoid content by the encapsulation of propolis in nanoparticles, result also demonstrated by electrochemical analysis.

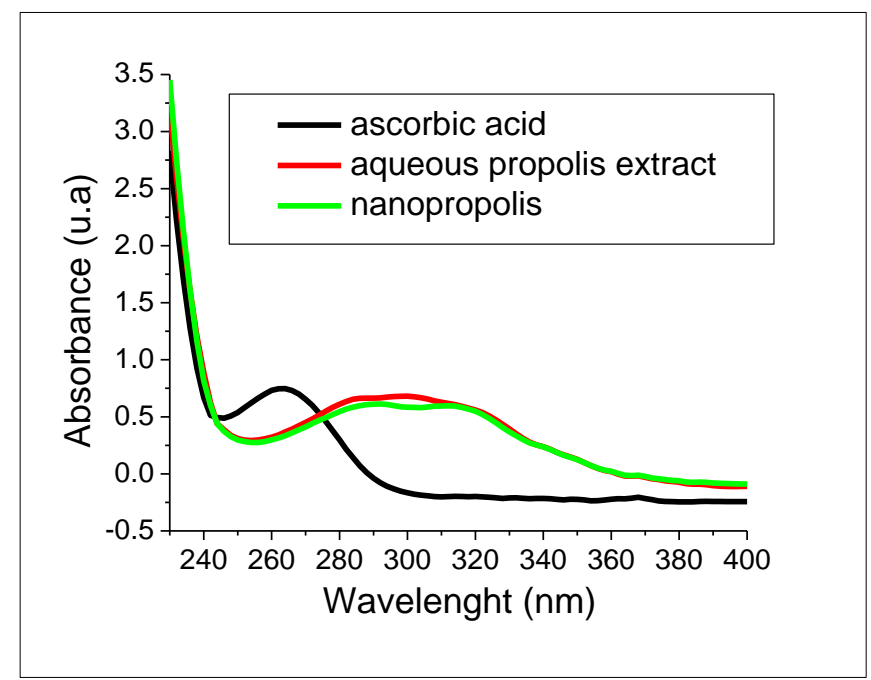

Figure 8. UV-Vis spectra of ascorbic acid $\left(2.5 \times 10^{-4} \mathrm{M}\right)$, aqueous propolis extract (1:500) and nanopropolis (1:10)

While the aqueous extract demonstrated higher antioxidant activity compared to the ethanolic one, a large range of applications is now opened: new concept in nutraceuticals, improved efficiency as a natural antimicrobial and anti-biofilm agent with reduced toxicity, especially in dentistry where E. faecalis is known to form oral biofilms, or whenever the topical application of antibiotics failed, serving as alternatives to antibiotics and conventional antimicrobial agents.

\section{Conclusions}

Electrochemical assays were successfully applied in order to demonstrate the antioxidant activity of propolis extract encapsulated in chitosan nanoparticles, being a fast, low cost and easy tool for this purpose. Chitosan nanoparticles incorporating propolis extract, prepared by the TPP crosslinking procedure, revealed a maximum size distribution around $140 \mathrm{~nm}$, spherical shape and good stability, as demonstrated by TEM and DLS analysis. The HPLC profile of propolis extract and nanopropolis revealed that the main active compounds were well preserved upon nanoencapsulation in the chitosan matrix. The nanopropolis oxidation process was compared with that of ascorbic acid (usually used as a standard substance for evaluation of antioxidant activity), by applying cyclic voltammetry and differential pulse voltammetry, demonstrating a good antioxidant behavior. The results were also supported by UV-Vis spectroscopy, confirming that the content in phenolic acids and flavonoids was responsible for the antioxidant activity of propolis, even in nano-formulation. The results may offer new opportunities in nutraceuticals developments and alternatives to conventional antimicrobial agents.

Acknowledgements: This work was funded by the Project 123008, "SmartDoct - High quality programs for doctoral students and postdoctoral researchers of the University of Oradea for the increase of the relevance of research and innovation in the context of the regional economy", project funded by the Operational Programme Human Capital 2014-2020. The authors wish to acknowledge the support from the project "Cercetare de excelenţă la Universitatea din Oradea în domeniul materialelor avansate", CNFIS-FDI-2019-0702. 


\section{References}

1.SFORCIN, J.M., BANCOVA, V., Propolis: Is there a potential for the development of new drugs? $J$. Ethnopharmacol., 133, 2011, 253-260.

2.MARGHITAS, L.A., DEZMIREAN, D.S., BOBIS, O., Important developments in Romanian Propolis Research, Evid-Based. Compl. Alt., 2013, article ID 159392, http://dx.doi.org/10.1155/2013/159392 3.TAYSE DA CRUZ ALMEIDA, E., DELGADO DA SILVA, M.C., OLIVEIRA, J.M. DOS SANTOS, KAMIYA, R.U., ARRUDA, R.E. DOS SANTOS, VIEIRA, D.A., SILVA, V. DA COSTA, ESCODRO, P.B., BASILIO-JUNIOR, I.D., Gomes do Nascimento, T., J. Pharm. Anal., 7, 2017, 280-287.

4.BARRIENTOS, L., HERRERA, C.L., MONTENEGRO, G., ORTEGA, X., VELOZ, J., ALVEAR, M., CUEVAS, A., SAAVEDRA, N., SALAZAR, L.A., Chemical and botanical characterization of Chilean propolis and biological activity on cariogenic bacteria Streptococcus mutans and Streptococcus sobrinus. Braz. J. Microbiol., 44, 2013, 577-585.

5.OLIVEIRA, R.N., MANCINI, M.C., OLIVEIRA, F.C.S., PASSOS, T.M., QUILITY, B., THIRE, R.M.S., MICGUINESS, G.B., FTIR analysis and quantification of phenols and flavonoids of five commercially available plants extracts used in wound healing, Rev. Materia, 21, 2016, 767-779.

6.CAVALU, S., DAMIAN, G., DANSOREANU, M., EPR study of non-covalent spin labeled serum albumin and hemoglobin, Biophys. Chem., 99(2), 2002, 181-188.

7.RIGHI, A., NEGRI, G., SALATINO, A., Comparative Chemistry of Propolis from Eight Brazilian Localities. Evid-Based. Compl. Alt., 2013, 1-14.

8.CAVALU, S., BISBOACA, S., MATES, I.M., PASCA, P.M., LASLO, V., COSTEA, T., FRITEA, L., VICAS, S., Novel Formulation Based on Chitosan-Arabic Gum Nanoparticles Entrapping Propolis Extract Production, physico-chemical and structural characterization, Rev. Chim., 69(12), 2018, 37563760.

9.CAVALU, S., PROKISCH, J., LASLO, V., VICAS, S., Preparation, structural characterisation and release study of novel hybrid microspheres entrapping nanoselenium, produced by green synthesis IET Nanobiotechnol., 11, (14), 2017, 426 - 432.

10.DREVE, S., KACSO, I., POPA, A., RAITA, O., DRAGAN, F., BENDE, A., BORODI, GH., BRATU, I., Structural investigation of chitosan-based microspheres with some anti-inflammatory drugs, J. Mol. Struct., 997(1-3), 2011, 78-86.

11.ONG, T.H., CHITRA, E., RAMAMURTHY, S., SIDDALINGAM, R.P., YUEN, K.H., AMBU, S.P., DAVAMANI, F., Chitosan-propolis nanoparticle formulation demonstrates anti-bacterial activity against Enterococcus faecalis biofilms, Plos One, 31, 2017, 1-22.

12.AFROUZAN, H., AMIRINIA, C., MIRHADI, S.A., EBADOLLAHI, A., VASEJI, N., TAHMASBI, G., Evaluation of antimicrobial activity of propolis and nanopropolis against Staphylococcus aureus and Candida albicans, African Journal of Microbiology Research, 6(2), 2012, 421-425.

13.ROCHA, B.A., PIRES BUENO, P.C., LIMA LEITE VAZ, M.M-O., NASCIMENTO, A.P., FERREIRA, N.U., PADUA MORENO, G., RODRIGUES, M.R., DEMELLO COSTA-MACHADO, A.R., BARIZON, E.A., LIMA CAMPOS, J.C., OLIVEIRA, P.F., OLIVEIRA ACÉSIO, N., LIMA MARTINS, S.P., TAVARES, D.C., BERRETTA, A.A., Evaluation of a Propolis Water Extract Using a Reliable RP-HPLC Methodology and In Vitro and In Vivo Efficacy and Safety Characterisation, EvidBased. Compl. Alt., 2013, Article ID 670451, http://dx.doi.org/10.1155/2013/670451

14.PEREIRA, D., DE ANDRADE S. F., DE OLIVEIRA SWERTS M. S., MAISTRO, E. L., First in vivo evaluation of the mutagenic effect of Brazilian green propolis by comet assay and micronucleus test, Food. Chem. Toxicol., 46(7), 2008, 2580-2584.

15.MOHTAR, G., MESSINA, G.A., BERTOLINO, F.A., PEREIRA, S.V., RABA, J., NAZARENO, M.A., Comparative study of different methodologies for the determination the antioxidant activity of Venezuelan propolis, Microchem. J., 158, 2020, 105244, https://doi.org/10.1016/j.microc.2020.105244 16.JASPRICA, I., BOJIC, M., MORNAR, A., BESIC, E., BUCAN, K., MEDIC-SARIC, M., Evaluation of Antioxidative Activity of Croatian Propolis Samples Using DPPH and ABTS ${ }^{+}$Stable Free Radical Assays, Molecules, 12(5), 2007, 1006-1021. 
17.MIERE (GROZA), F., TEUSDEA, A.T., LASLO, V., FRITEA, L., MOLDOVAN, L., COSTEA, T., UIVAROȘAN, D., VICAS, S.I., PALLAG, A., Natural Polymeric Beads for Encapsulation of Stellaria media Extract with Antioxidant Properties, Mater. Plast., 56(4), 2019, 671-679.

18.TUGBA, O., GULCE, S.K., ERGUL, M.A., DILEK, B. ESRA, C., Evaluation of Turkish propolis for its chemical composition, antioxidant capacity, anti-proliferative effect on several human breast cancer cell lines and proliferative effect on fibroblasts and mouse mesenchymal stem cell line, J. Apicult. Res., 57(5), 2018, 627-638.

19.CAN, Z., YILDIZ, O., ŞAHIN, H., ASADOV, A., KOLAYLI, S., Phenolic Profile and Antioxidant Potential of Propolis from Azerbaijan, Mellifera, 15(1), 2015, 16-28.

20.DĂRĂBAN, A., OLAH, N.K., BURTESCU, R.F., FURTUNĂ, FP., HANGANU, D., SIMON, I., BOJIŢĂ, M., HEGHEŞ, C.S., FILIP, L., The evaluation of antioxidant capacity of propolis originating from western Romania, Farmacia, 67(1), 2019, 111-116.

21.REŞAT, A., KUBILAY, G., BIRSEN, D., MUSTAFA, Ö., SALIHA, E.Ç., BURCU B., IŞIL BERKER, K., DILEK, Ö., Comparative Evaluation of Various Total Antioxidant Capacity Assays Applied to Phenolic Compounds with the CUPRAC Assay, Molecules, 12, 2007, 1496-1547.

22.JURCA, T., VICAS, L.G., TOTH, I., BRAUN, M., MARIAN, E., TEUSDEA, A., VICAS, S., MURESAN, M., Mineral elements profile, bioactive compounds and antioxidant capacity of wild blueberry and of pharmaceutical preparations from Blueberry (Vaccinum Myrtillus), Farmacia, 64(4), 2016, 581-587.

23.MALDONADO, L., MARCINKEVICIUS, K., BORELLI, R., GENNARI, G., SALOMÓN, V., ISLA, M. I., VERA, N., BORELLI, V., Differentiation of argentine propolis from different species of bees and geographical origins by UV spectroscopy and chemometric analysis, Journal of the Saudi Society of Agricultural Sciences, 19, 2020, 185-191.

24.KOSTIC, D. A., MITIC, S., MITIC, M., MARINKOVIC, G., A new kinetic method using UV-VIS spectrophotometry for determination of caffeic acid in propolis, Journal of Food Safety and Food Quality 70(4), 2019, 91-124.

25.ASEM, N., ABDUL GAPAR, N.A., ABD HAPIT, N.H., OMAR, E.A., Correlation between total phenolic and flavonoid contents with antioxidant activity of Malaysian stingless bee propolis extract, $J$. Apicult. Res., 59(4), 2019, 437-442.

26.MASEK, A., CHRZESCIJANSKA, LATOS M., KOSMALSKA, A., Electrochemical and spectrophotometric characterization of propolis antioxidants properties, Int. J. Electrochem. Sci., 14, 2019, 1231-1247.

27.RISTIVOJEVIC, P., TRIFKOVIC, J., STANKOVIC, D.M., RADOICIC, A., MANOJLOVIC, D., MILOJKOVIC-OPSENICA, D., Cyclic voltammetry and UV/Vis spectroscopy in combination with multivariate data analysis for the assessment of authenticity of poplar type propolis, J. Apicult. Res., 56(5), 2017, 559-568.

28.FALCAO, S.I., TOMAS, A., FREIRE, C., VILAS-BOAS, M., A voltammetric tool for the evaluation of propolis antioxidant activity, Eur. Food Res. Technol., 242(8), 2016, 1393-1401.

29.BELFAR, M.L., LANEZ, T., REBIAI, A., GHIABA, Z., Evaluation of Antioxidant Capacity of Propolis Collected in Various Areas of Algeria Using Electrochemical Techniques, Int. J. Electrochem. Sci., 10, 2015, $9641-9651$.

30.REBIAI, A., LANEZ, T., BELFAR, M.L., In vitro evaluation of antioxidant capacity of Algerian propolis by spectrophotometrical and electrochemical assays, Int. J. Pharmacol., 7(1), 2011, 113-118.

31.LASKAR, R.A., SK, I., ROY, N., BEGUM, N.A., Antioxidant activity of Indian propolis and its chemical constituents, Food Chem., 122, 2010, 233-237.

32.RUSU, M.E., GHELDIU, A-M., MOCAN, A., MOLDOVAN, C., POPA, D-S., TOMUTA, I., VLASE, L., Process Optimization for Improved Phenolic Compounds Recovery from Walnut (Juglans regia L.) Septum: Phytochemical Profile and Biological Activities, Molecules, 23, 2018, 2814. 
33.ANTONESCU (MINTAS), I.A., JURCA, T., GLIGOR, F., CRACIUN, I., FRITEA, L., PATAY, E.B., MURESAN, M., UDEANU, D.I., IONIȚĂ, C.A., ANTONESCU, A., BODOG, F., Comparative phytochemical and antioxidative characterization of Trifolium pratense L. and Ocimum basilicum L. Farmacia, 67(1), 2019, 146-153.

34.DOBJANSCHI, L., FRITEA, L., PATTAY, E.B., TAMAS, M., Comparative study of the morphological and phytochemical characterization of Romanian Solidago species, Pak. J. Pharm. Sci., 32(4), 2019. 1571-1579.

35.CASTRO, C., MURA, F., VALENZUELA, G., FIGUEROA, C., SALINAS, R., ZUÑIGA, M., C., TORRES, J. L., FUGUET, E., DELPORTE, C., Identification of phenolic compounds by HPLC-ESIMS/MS and antioxidant activity from Chilean propolis, Food. Res. Int., 64, 2014, 873-879.

36.HROBONOVA, K., LEHOTAY, J., CIZMARIK, J., Determination of Some Phenolic Acids in Propolis by an HPLC Method, J. Liq. Chromatogr. R. T., 31(8), 2008, 1213-1226.

37.PELlATI, F., ORLANDINI, G., PINETTI, D., BENVENUTI, S., HPLC-DAD and HPLC-ESIMS/MS methods for metabolite profiling of propolis extracts, J. Pharm. Biomed. Anal., 55, 2011, 934948.

38.KASIOTIS, K.M., ANASTASIADOU, P., PAPADOPOULOS, A., MACHERA, K., Revisiting Greek Propolis: Chromatographic Analysis and Antioxidant Activity Study, Plos One, 19, 2017, 1-27.

39.GRENHA, A., SEIJO, B., REMUÑAN-LOPEZ, C., Microencapsulated chitosan nanoparticles for lung protein delivery. Eur. J. Pharm. Sci., 25, 2005, 427-437.

40.TEIJEIRO-OSORIO, D., REMUÑAN-LÓPEZ, C., ALONSO, M.J., New Generation of Hybrid Poly/Oligosaccharide Nanoparticles as Carriers for the Nasal Delivery of Macromolecules Biomacromolecules, 10, 2009, 243-249.

41.FRITEA, L., TERTIŞ, M., CRISTEA, C., COSNIER, S., Săndulescu, R., Simultaneous Determination of Ascorbic and Uric Acids in Urine Using an Innovative Electrochemical Sensor Based on $\beta$-Cyclodextrin, Anal. Lett., 48(1), 2015, 89-99.

42.FRITEA, L., TERTIŞ, M., TOPALĂ, T.L., SĂNDULESCU, R., Electrochemical and spectral study of cyclodextrins interactions with some pharmaceutical substances, Farmacia, 61(6), 2013, 1054-1068. 43.BADEA, M., CHIPEREA, S., BĂLAN, M., FLOROIAN, L., RESTANI, P., MARTY, J-L., IOVAN, C., ŢIT, DM., BUNGĂU, S., TAUS, N., New approaches for electrochemical detection of ascorbic acid, Farmacia, 2018, Vol. 66, 1, 83-87.

44.NICUlAE, M., STAN, L., PALL, E., PASTIU, A.I., BALACI, I.M., MUSTE, S., SPÎNU, M., In vitro Synergistic Antimicrobial Activity of Romanian Propolis and Antibiotics against Escherichia coli Isolated from Bovine Mastitis, Not Bot Horti Agrobo, 43(2), 2015, 327-334.

45.KUMAZAWA, S., HAMASAKA, T., NAKAYAMA, T., Antioxidant activity of propolis of various geographic origins, Food Chem., 84, 2004, 329-339.

46.GARCÍA-VIGUERA, C., FERRERES, F., TOMAS-BARBERÁN, F.A., Study of Canadian Propolis by GC-MS and HPLC, Z. Naturforsch. 48c, 1993, 731-735.

47.MEDANA, C., CARBONE, F., AIGOTTI, R., APPENDINO, G., BAIOCCHI, C., Selective Analysis of Phenolic Compounds in Propolis by HPLC-MS/MS, Phytochem. Anal. 19, 2008, 32-39.

48.CAN, Z., YILDIZ, O., ŞAHIN, H., ASADOV, A., KOLAYLI, S., Phenolic Profile and Antioxidant Potential of Propolis from Azerbaijan, Mellifera, 15(1), 2015, 16-28.

49.ECEM BAYRAM, N., GERÇEK, Y.C., CEHAVIR ÖZ, G.C., Screening for antioxidant capacity, pollen types and phytochemical profile by GC/MS and UHPLC from propolis, Progr. Nutr., 22(3), 2020, DOI: $10.23751 /$ pn.v22i3.8416.

50.BRUSCHI, M.L., FRANCO, S.L., GREMIÃO, M.P.D., Application of an HPLC Method for Analysis of Propolis Extract, J. Liq. Chromatogr. R. T., 26(14), 2003, 2399-2409.

51.GATEA, F., HANGANU, A., TEODOR, E.D., RADU, G.L., GILLE, E., Statistical Approach of High - performance Liquid Chromatography with Diode Array Detection Data from Romanian Propolis, Rev. Chim., 66(12), 2015, 1938-1942. 
52.BOLFA, P., VIDRIGHINESCU, R., PETRUTA, A., DEZMIREAN, D., STAN, L., VLASE, L., DAMIAN, G., CATOI, C., FILIP, A., CLICHICI, S., Photoprotective effects of Romanian propolis on skin of mice exposed to UVB irradiation, Food Chem. Toxicol., 62, 2013, 329-342.

53.FRITEA, L., TERTIŞ, M., CRISTEA, C., SĂNDULESCU, R., New $\beta$-Cyclodextrin Entrapped in Polyethyleneimine Film-Modified Electrodes for Pharmaceutical Compounds Determination, Sensors, 13, 2013, 16312-16329.

$\overline{\text { Manuscript received: } 5.05 .2020}$ 